\title{
Editorial: Transforming Democracy
}

\section{Upfront}

\author{
WENDY HARCOURT
}

Putting together this issue, I was forcibly reminded of the challenges thrown out to Development readers by the Volume 48 Number 3 on 'Peacebuilding through justice'. In that issue, Alejandro Bendaña in his lead article raised strong concerns about development assistance policies that identified nation-building with democracy promotion, characterized by Western 'liberal democratic property-protecting institutions'. He stated that democracy is a contested concept that can only be understood as contextually specific, and he questioned if genuine self-determination was possible given global power dynamics. He asked that we consider democracy together with self-determination and look at democracy as more than the procedure of electoral competition, but as a practice founded on the substantive values of social justice and equality. He concluded:

It is time to swing the clock, not backward, but forward towards the construction of ever more democratic gender sensitive differentiated democracies with economies based more on solidarity than on profit.

Development 50.1 takes up this challenge to put into context questions of democracy and democratization as something more than just a procedure of votes but rather as something deeply connected with the values of social justice, gender equity, and equality. It highlights some of the problems associated with conventional approaches to democratization, and gives insights into a number of alternative workings of democracy in theory and practice. It begins from the premise that democracy has a history shaped by diverse ideological dimensions and by specific social circumstances. We live in times when many in both the Global North and South are conscious that democracy is a goal as much as a reality, something that is alive and well in many localities but also operating with tremendous deficit in others.

The journal pushes us beyond the familiar fundamental processes of democratization: for example, free and fair elections and basic political and civil rights. It explores the promise of democracy that lies in the political equality of all citizens as the way forward to reverse injustice, discrimination, and inequality. In contextualizing the practice of democracy, the journal reveals the current downsides for many old and new democracies. Even if most countries now have elections, citizens all over the world are expressing increasing disappointment and disaffection with the results of these democratic 
processes. It seems that elections and basic civil and political rights do not suffice for true democratization. The journal examines critically this failure to consolidate democracy, as an ill-fitting match between liberal democracy and the economic and social realities particularly for many countries in the South, but also for the socially and economically excluded of the North.

The focus of the journal then, is not on electoral provision of democracy although several articles do describe in technical detail how to promote fair elections that support local participation and, in particular, the electoral provisions that enable women's representation and political participation. Most though describe the disappointments of new democracies and the struggles of civil society working to transform processes of democratic innovation in local forms of democracy found in social movements and citizenship organizations.

As Isabel Hilton and Anthony Barnett argue:

Democracy remains the foundation of human freedom, human security and even human survival in the 21st century. But if this continue to be true, these new challenges require a new response: to strengthen the principles and values of democracy and make them newly relevant, so that they may engage with the changes taking place across the world.

From South Africa to Central Asia, Central and Latin America to Eastern Europe, the articles show how processes of democracy are played out in a complex world, marked by difficult economic and social contexts, often ones that cloud the original vision of equality, human rights and social justice. They show how genuine attempts to recast power and establish participation and democratic institutions that promote social justice confront many complex and competing forces that prevent true democracy. Viviene Taylor comments:

the international debate on governance has been reduced to what kind of government is needed for the global market. ...Countries in the SADC region have been in a process of democratic transition for more than a decade. For many, in the wake of deco lonization, moving from minority undemocratically elected governments to majority rule was a necessary part of political reform processes. Not surprisingly, in these countries the process of demo- cratization is accompanied by turbulence and ongoing contestation for both state power and access to resources denied to previously disenfranchized people. But democratisation and decentralization in some countries is slow to translate into active citizenship and the reduction of poverty and inequalities. ... political change has not translated into advances for those who were previously excluded from decision-making ... Women, the landless, former combatants, the unemployed and those in chronic poverty and deprivation experience ongoing hardship and marginalization which is further aggravated by the HIV/AIDS pandemic ravaging most of the region.

A vision for equality and justice, including the plea for a feminist democracy by Helen O'Connell and others where 'a new politics would have real democracy at every level - at home, in the workplace, and at local, national, and international levels' seems to be far from the practice of political democracy today. Shamim Meer asks us to consider ways of questioning the limited neoliberal versions of democracy and the technocratic version of addressing women's subordination at the same time as they need to seek ways of building organizations.' Gillian Youngs proposes that we look at how the Internet offers one possible new dimension for political being and expression.

The journal in reflecting on the good and the bad of democracy in different contexts around the world, shows how there is a strong shared awareness that democracy means far more than electoral politics. Citizens are increasingly challenging bad governance and the lack of democratization, and are looking to transform democracy so that it becomes a vehicle for change that can slowly build a culture of participation and autonomy among citizens.

These challenges of democracy start with the Mandavilles in their introduction where they point out the many problems with the democracy assistance mechanisms' and argue that there is a capacity for US-led democracy aid programmes for critical self-reflection on the meaning and process of democracy. Despite the democratic paradox' as it is called where outcomes of democratic processes may not favour those that promoted the electoral process, and indeed can be then challenged or not honoured, the Mandavilles still see ways in which democratization efforts can be 
reformulated. They suggest the promotion of democracy needs to be based on insights from social theory, some of which they give in the article, and closer attention to the local histories and legacies of power relationships (and various modes of mediating them) that shape the political realities of the Global South. Their concerns are echoed by Cor van Beuningen who argues that democracy promotion beyond 'technical assistance' in elections is a sensitive matter:

Many observers, democratic and non-democratic alike, feel uneasy about the motives behind the hard power used by the US to promote freedom and democracy abroad, and this has greatly fuelled the present backlash against democracy promotion as such.

Jesse C. Ribot suggests that more work needs to be done on institutional choice and in order to establish, consolidate and sustain local democracy as part of a process of institutional pluralism where 'citizens and all local institutions can interact to coordinate and improve public accountability and responsiveness - so that decisions and services reflect local aspirations and needs.' The backdrop to the articles is how to promote participatory self-determined democratic processes in the face of the geopolitical aspirations of global hegemons be they economic, military or political. This concern for autonomous democracy processes pushes a little deeper into not just the theory or 'delivery' of democracy, but into the practice of democracy. In articles from Africa, the Philippines, Central America and Mexico, we see that there are positive examples of local democratic practice where civil society is transforming democracy. These experiments in democratic practice are engaging women, men and even children (see Fabrizio Terenzio's contribution) in new modalities of political ownership and change even in rural areas. Michael Clulow describes how women's organizations in urban and rural Central America are challenging the patriarchal machista culture, gender blindness as well as financial restraints of policy and becoming engaged in local politics, leading to major changes in democratic consultation processes as well as better services to combat gender-based violence. Sonja Lokar political engagement in Central and Southern Eastern Europe, describing how women, although at first excluded from new regimes, have fought to enter political spaces and are now a part of political processes.

The most graphic picture of democracy in practice, however, comes from Gustavo Esteva in his description of the Popular Assembly of the Peoples of Oaxaca (Asamblea Popular de los Pueblos de Oaxaca) APPO. His brief contribution describes his own struggle alongside other citizens to change fraud and manipulation of the electoral system, establish a truly participatory democracy, based on more civil involvement in the workings of government and to extend and deepen autonomous democracy. What he calls the radical democracy of Oaxaca is based on the experience and practice of the municipalities in Oaxaca, which reflect as closely as possible the political traditions of Oaxaca's indigenous communities. These democratic practices, which are being severely challenged by the State government, aim to coordinate citizens' collective endeavours, and as Esteva states 'to strengthen the social networks of Oaxacans and reinforce their dignity and autonomy ... attempting to rebuild society from the bottom up and create a new set of social relations.'

Not all of us can be on the frontlines like Esteva and other courageous activists, as this goes to print there are ongoing violent clashes in Oaxaca. But many of us, I would agree with Hilton and Barnett, want to address the current democratic deficits and the insidiousness of different forms of fundamentalism, wherever they are opezrating. Democratic institutions need to change in ways that allow civil society distinct from the politics of the state and the interests of the market to express itself so that the dominant human values are not guided by power, violence or greed but by open-minded, participatory and democratic citizenship. We can no longer shy away from a sensitive and difficult discussion on democracy. As this journal attests, such a dialogue needs to be based not on universalizing blueprints for democracy but on conversations grounded in knowledge of local realities and awareness of the global economic, political and social power games in which the practice of democracy is being played out. 